\title{
Peran Perempuan dalam Keputusan Desain pada Interior Residensial di Kawasan Bantaran Kali Buntu Karangwaru Yogyakarta
}

\author{
Artbanu Wishnu Aji \\ Program Studi Desain Interior Institut Seni Indonesia Yogyakarta \\ Email: artbanu@isi.ac.id
}

\begin{abstract}
Abstrak
Sebuah hunian atau lingkungan buatan pada dasarnya merupakan hasil keputusan-keputusan desain yang berasal dari pihak yang terlibat di dalamnya. Hingga saat ini peran gender dalam pengambilan keputusan desain ini masih belum banyak diteliti. Budaya masyarakat Jawa yang lebih memberikan peran sentral kepada laki-laki untuk mengambil keputusan-keputusan penting menjadikan perempuan tertutupi perannya dalam proses pengambilan keputusan tersebut. Penelitian ini bertujuan untuk mendiskripsikan peran perempuan dalam pengambilan keputusan desain residensial di kawasan Kali Buntu Yogyakarta. Sepuluh perempuan dipilih sebagai responden dalam penelitian ini. Metode wawancara mendalam semi-terstruktur digunakan untuk menggali keterlibatan mereka dalam proses penentuan keputusan desain seperti arah hadap rumah, warna, pemilihan perabot dan pengaturan tata letak. Hasilnya menunjukkan bahwa perempuan yang memiliki kontribusi kepemilikan dapat bersama-sama menentukan keputusan desain dengan partner laki-lakinya sementara perempuan yang tidak memiliki kontribusi kepemilikan cenderung untuk menyerahkan keputusan desain pada partner laki-lakinya.
\end{abstract}

Kata kunci: Perempaun, Keputusan, Desain

\begin{abstract}
Residentials design and built enviornments are the result of design decision between clients and designers. In Javanese culture building a house is the affair of the men, they make most of the design decision and orchestrating the entire endevour as a sole decision maker.Until recently, research on gender's role in design decision has not been explored extensively. This research aimed to describe women's role in design dicision of their residential design and their inner drive to make that dicision. Ten women were selected along the Buntu River in Karangwaru neighborhood's residents in Yogyakarta as respondents. Semi-structured interview were used as data collecting method. Using qualitative data analysis to extract the interview, we found that women's role in design dicision were driven by their ownership of the property. Their ownership make them powerfull enough to share design dicision with their male partner.
\end{abstract}

Keywords: Women, Dicision, Design

\section{Pendahuluan}

Desain adalah hasil dari berbagi keputusan yang diambil oleh klien dan desainer atau oleh perencana baik profesional maupun non-profesional. Proses desain yang dilakukan oleh desainer akan menghasilkan serangkain alternatif solusi yang membutuhkan keputusan desain seperti lokasi mana yang terbaik, material apa yang akan digunakan, warna apa yang cocok serta gaya apa yang akan diterapkan. Alternatif-alternatif ini merupakan bahan diskusi antara desainer dan klien dalam upaya kolaboratif meraka untuk menghasilkan hasil akhir yang terbaik. Perencana non-profesional juga mengalami pengalaman yang sama, meskipun dalam konteks yang berbeda. Arsitektur dan 
desain vernakular biasanya telah memiliki pola dan kebiasaan dalam hal pemakaian gaya, material dan warna tertentu, namun demikian permasalahan desain seperti lokasi yang berbeda serta lingkungan sekitar yang khas akan memunculkan serangkaian alternatif yang harus diputuskan oleh perencana dan pelaksana. Rumah joglo yang terletak di pinggir sungai akan memunculkan persoalan seperti ke mana arah depan rumah harus dihadapkan.

Pembangunan rumah di Jawa terutama di Yogyakarta secara umum menjadi ranah bagi kaum lakikali. Hal ini disebabkan karena pembangunan rumah memerlukan tenaga fisik dan kerjasama dengan pihak lain seperti tukang dan mandor yang umumnya juga didominasi oleh laki-laki. Perempuan biasanya terlibat dalam penyediaan logistik seperti makan siang dan sajian pengiring makan. Dimasa lampau proses pembangunan ini memerlukan ritual dan acara selamatan yang melibatkan pemuka masyarakat dari kalangan laki-laki dan dihadiri oleh para tetangga lelaki di sekitar lokasi pembangunan. Setalah upacara ritual selesai maka perkerjaan pembangunan rumah akan dilakukan oleh para tukang atau pada beberapa kasus dilakukan bergotong royong oleh para tetangga lelaki.

Sejalan dengan perkembangan dan perubahan sosial pada masyarakat Yogyakarta, pembangunan rumah kini tidak selalu mengikuti pola yang sama dengan gambaran di atas. Pemilik rumah bisa melakukan pembangunan tanpa melibatkan tetangga ataupun upacara ritual untuk memulai pembangunan. Hal ini menimbulkan dinamika baru dalam proses pembangunan rumah dalam konteks masyarakat Yogyakarta modern dan memunculkan pertanyaan apakah proses pembangunan rumah masih menjadi ranah bagi kaum laki-laki atau bisa juga dilakukan oleh kaum perempuan. Beberapa penelitian dan tulisan menunjukkan bahwa perempuan telah mengambil peran dalam kegiatan perancangan seperti dikemukakan oleh Putri dan Rucita (2013) yang menyatakan bahwa dalam proses desain melibatkan responden perempuan sebagai narasumber untuk menentukan kebutuhan dan preferensi desain sebuah interior pusat kecantikan. Namun demikian tulisan ini tidak menjelaskan bagaimana peran perempuan dalam proses pengambilan keputusan desain.

Penelitian lain memaparkan tentang pengaruh faktor internal dan faktor eksternal yang mempengaruhi perempuan dalam peran pengambilan keputusan dalam keluarga. Setiawati et.al (2017) lebih lanjut menjelaskan bahwa faktor internal merupakan bentuk tanggung jawab perempuan dalam mengemban tugas sebagai ibu rumah tangga sedangkan faktor eksternal merupakan bentuk kepercayaan suami terhadap istri dalam kemampuan untuk mengambil keputusan. Hal ini menunjukkan bahwa jika suami memiliki kepercayaan terhadap kemampuan istri maka peran perempuan dalam mengambil keputusan dalam keluarga akan semakin besar. Penlitian ini tidak secara langsung membahas tentang keputusan perempuan terhadap pemilihan desain interior namun memberikan gambaran faktor-faktor yang memperkuat peran mereka dalam pengambilan keputusan keluarga.

Siswati dan Puspitawati (2017) meneliti tentang peran gender, pengambilan keputusan dan kesejahteraan pada keluarga yang suami dan istrinya bekerja. Hasil pada variabel pengambilan keputusan menunjukkan bahwa keputusan keluarga masih di dominasi oleh salah satu pihak walaupun pada kategori pengambilan keputusan yang berhubungan dengan permasalahan sosial dan hubungan keluarga terdapat pembagian yang dilaksanakan secara seimbang. Meskipun kategori pengambilan keputusan meliputi aspek ekonomi, anak, kesehatan, hubungan sosial dan pemenuhan kebutuhan, penelitian ini tidak membahas tentang keputusan suami-istri terhadap pemenuhan tempat tinggal dan kenyamanan tinggal.

Penelitian yang menyinggung relasi kekuasaan dalam pengambilan keputusan antara suami istri yang berhubungan dengan fisik rumah hunian adalah penelitian Nurhamida (2013). Peniltian ini menjelaskan bahwa pembagian pekerjaan yang berhubungan dengan perbaikan rumah, furnitur dan alat rumah tangga dilakukan oleh suami. Namun hal ini tidak menjelaskan tentang relasi pengambilan keputusan dalam ketiga aktifitas tersebut hanya pembagian peran yang menunjukkan peran suami lebih dominan dalam tiga aktifitas. 
Penelitian-penelitian di atas menunjukkan bahwa peran perempuan dalam pengambilan keputusan desain di proses perancangan masih belum banyak dilakukan. Penelitian ini bertujuan untuk mendiskripsikan peran perempuan dalam pengambilan keputusan desain interior di ranah desain residensial yang meliputi penentuan arah hadap, warna, perabot dan pemilihan tata letak. Dua pertanyaan penelitian yang diajukan dalam penelitian ini adalah siapa yang lebih dominan dalam menentukan keputusan keputusan desain dan faktor-faktor apa saja yang mempengaruhi keputusan-keputusan desain tersebut dari sudut pandang kaum perempuan.

\section{Metode}

Penelitian ini menggunakan metode-diskriptif kualitatif. Data dikumpulkan dengan menggunakan wawancara semi-terstruktur untuk melihat proses awal penentuan pembangunan rumah dan penataan serta pengisian perabot setelah rumah tersebut siap huni. Leavy (2017) menjelaskan bahwa pertanyaan semi-terstruktur memungkinkan peneliti untuk memodifikasi pertanyaan yang telah disiapkan kisi-kisi utamanya. Modifikasi ini diperlukan untuk memperdalam informasi yang dibutuhkan dalam proses pengumpulan data.

Responden yang dipilih dalam penelitian ini berjumlah sepuluh (10) perempuan yang bertempat tinggal di wilayah bantaran Kali Buntu Karangwaru. Wilayah ini terletak di kecamatan Tegalrejo Yogyakarta dengan penduduk yang sebagain besar bekerja disektor non-pertanian. Wilayah ini dipilih karena secara geografis memiliki keunikan yang berbatasan antara Kabupaten Sleman dan kotamadya Yogyakarta. Perbatasan ini menyebabkan kondisi sosial masyarakat di wilayah ini memiliki karakter yang menggabungkan antara wilayah urban dan sub-urban di mana nilai-nilai tradisional sudah mulai bergeser namun belum ditinggalkan sepenuhnya.

Data dianalisis dengan menggunakan teknik koding data yang dimulai dengan menandai unit analisis dengan kode. Unit analisis adalah kalimat-kalimat dalam transkrip interview dan diberi kode awal secara literal ( kalimat apa adanya ). Selanjutnya pengkodingan ditingkatkan dengan menggabungkan beberapa kode literal dalam kode katagoris yang lebih besar dan abstrak. Selanjutnya Tema-tema mulai dihasilkan dalam proses penggabungan kode-kode abstrak tersebut.

Interpertasi data dilakukan dengan memberikan pemaknaan dan terhadap tema-tema yang dihasilkan dari tahap abstraksi data. Pemaknaan juga dilakukan dengan membandingkan teori dengan data yang ditemukan untuk memberikan gambaran lebih luas dan menguatkan hasil analisis. Selanjutnya hubungan antar tema dan pola-pola yang muncul dalam data didiskripsikan untuk menjawab pertanyaan penelitian.

\section{Pembahasan}

Pengambilan keputusan dalam desain menurut Almendra dan Christiaans (2009) dipengaruhi oleh faktor-faktor seperti pengetahuan dan pengalaman terhadap persoalan desain yang dihadapi, informasi dan nilai informasi yang dianggap penting oleh desainer untuk digunakan dalam pemecahan masalah dan sketsa sebagai upaya untuk mencari ruang solusi. Sketsa tidak selalu berupa gambar-gambar fisik namun dapat pula berbentuk gambaran imajinatif yang berhubungan dengan hasil untuk dapat dicapai dalam proses desain.

Pengambilan keputusan menurut Choi et.al (2004) dipengaruhi oleh latar belakang budaya. Masyarakat barat cenderung untuk lebih berhati-hati dalam mengambil keputusan dibandingkan dengan masyarakat Asia terutama Cina yang cenderung berani mengambil resiko atas 
keputusannya. Hal ini disebabkan karena masyrakat Asia memiliki jejaring sosial yang baik sehingga mampu menjadi penyelamat ketika mereka menghadapi krisis ketika keputusannya tidak berhasil dengan baik.

Choi et.al (2004) menambahkan bahwa masyarakat barat cenderung berpikir analitis sedangkan masyarakat Asia timur memiliki pola berpikir holistik. Hal ini menyebabkan pengambilan keputusan masyarakat Asia timur bertumpu pada informasi yang saling berhubungan dibanding kelompok masyarakat barat yang mengambil informasi spesifik dan tersisolasi untuk dasar pengambilan keputusannya.

Penelitian ini berfokus pada peran perempuan dalam konteks budaya Jawa di wilayah bantaran sungai. Meskipun tidak semua responden berlatar belakang budaya Jawa namun konteks tempat tinggal mereka dapat mempengaruhi pola-pola keputusan yang diambil seperti tatanan fisik yang bersifat lokal-kultural. Data yang dihasilkan akan dikelompokkan sesuai dengan kategori keputusan yang diteliti yaitu arah hadap, warna, perabot dan tata letak.

\section{Arah Hadap Rumah}

Tema utama yang muncul dalam penentuan arah hadap rumah adalah kemudahan akses dan estetika. Salah seorang responden mengungkapkan bahwa pertimbangan arah hadap didasarkan pada musyawarah bersama antara suami istri dan pada akhirnya lebih mengutamakan pertimbangan perempuan yang memilih arah hadap rumah ke jalan kampung daripada ke arah sungai (gb.1).

Kondisi sungai sewaktu rumah responden dibangun masih dalam keadan kotor secara visual kurang menarik sehingga istri memilih untuk menghadapkan rumah ke jalan kampung. Pernyataan istri mangandung nada yang berbeda ketika dihadapkan pada kondisi sungai saat ini yang terlihat lebih baik. Namun demikian tidak ada rencana untuk mengubah arah hadap rumah meskipun pemandangan sungai kini terlihat lebih baik.

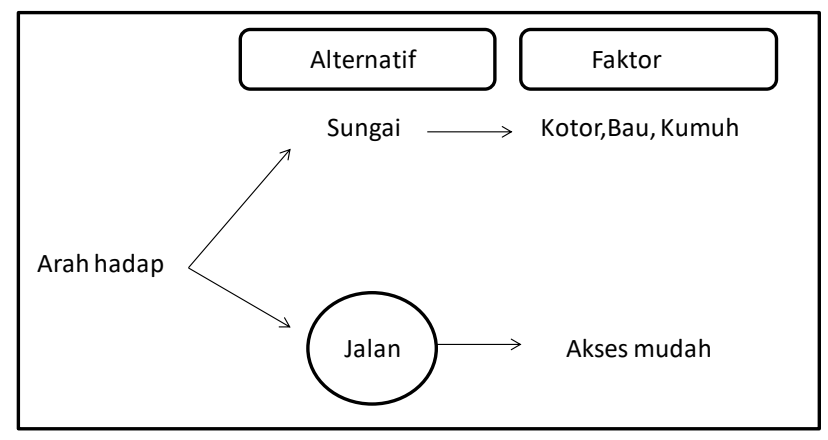

Gambar 1 Alternatif, keputusan dan faktor penentu keputusan oleh perempuan dalam arah hadap rumah ( sumber: Analisis, 2020)

Subyek lain mengungkapkan bahwa jalan lebih utama sebagai arah hadap rumah dan mengambil keputusan dominan dalam menentukan arah hadap ini. Status kepemilikan terhadap lahan memungkinkan perempuan untuk lebih berperan dalam menentukan arah hadap rumah. Tanah milik keluarga dan tanah waris merupakan sumber kepemilikan lahan bagi kaum perempuan, jika mereka memiliki kontrol kepemilikan maka arah hadap rumah lebih didominasi oleh perempuan.

Kampanye pemerintah daerah dan ajakan Sri Sultan untuk menghadapkan rumah ke arah sungai sebetulnya dapat menjadi faktor penentu dalam menentukan arah hadap rumah. Namun rumah 
rumah yang diteliti telah didirikan sebelum kampanye untuk menghadapkan rumah ke sungai dimulai sehingga faktor yang cukup signifikan ini tidak menjadi penyumbang bagi penentu keputusan arah hadap rumah.

Selain kepemilikan tanah yang menjadi penentu bagi perempuan untuk mengambil keputusan arah hadap rumah, kemungkinan mengapa perempuan memilih arah hadap rumah menghadap jalan adalah faktor kesejahteraan dan kesehatan keluarga. Sungai yang kumuh, kotor dan bau menimbulkan kekhawatiran bagi perempuan terhadap kesehatan anggota keluarga lainnya.

Jika tanah merupakan warisan keluarga suami maka istri cenderung untuk tidak ikut terlibat dalam menentukan arah hadap rumah. Hal ini selaras dengan kebudayaan masyarakat Jawa yang biasanya enggan ikut campur dalam perkara warisan karena dianggap "saru" (tabu). Keterlibatan aktif dalam mengurus harta warisan dapat menimbulkan kesan serakah dan terkesan mengurusi sesuatu yang bukan urusannya.

Selain faktor kultural dan pragmatis yang menjadi dasar pengambilan keputusan arah hadap rumah, terdapat satu alasan lain yang menjadi determinan utama yaitu ketersedian lahan. Jika lahan mereka hanya tersisa satu muka maka tidak ada pilihan untuk menghadapkan rumah tersebut ke arah lain.

\section{Warna}

Pemilihan warna untuk rumah tinggal dilakukan secara bersama-sama antara suami dan istri. Kompromi yang muncul dapat berupa satu warna untuk bagian luar dan satu warna lain untuk bagian dalam sehingga keinginan kedua pihak bisa terpenuhi (gb.2).

Pemilihan warna tidak menjadi prioritas bagi perempuan dalam ikut serta untuk mengambil keputusan. Pilihan warna yang diambil oleh suami biasanya bersifat netral seperti warna hijau. Warna juga terbagi menjadi dua yaitu warna bagian luar dan warna bagian dalam.

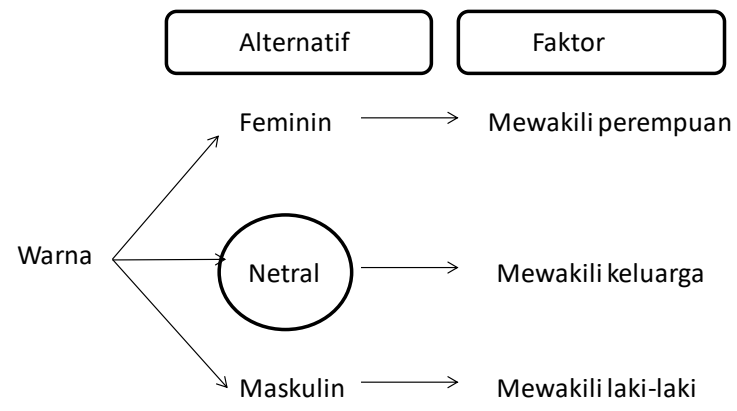

Gambar 2 Alternatif, keputusan dan faktor penentu keputusan oleh perempuan dalam pilihan warna ( sumber: Analisis, 2020)

\section{Perabot}

Pemilihan perabot menjadi dominasi perempuan ketika ruang tersebut banyak digunakan oleh perempuan. Tema "pemakaian" menjadi faktor utama dalam menentukan jenis dan model perabot. Material kayu menjadi pilihan utama bagi perabot dibandingkan material plastik. Kayu dinilai memiliki citra natural dan awet (gb.3)

Perabot menjadi elemen interior dimana perempuan memiliki peran besar dalam penentuan model dan variasinya hal ini disebabkan karena perempuan menganggap bahwa perabot dapat digunakan 
untuk menampilkan citra ruangan. Nuansa dan citra ruangan inilah yang menjadikan perempuan memiliki peran lebih besar dalam penentuan perabot.

Secara umum peran perempuan dalam penentuan perabot bertumpu pada kondisi finansial dan citra yang dihasilkan. Jika citra tidak dapat dijangkau dengan kondisi finansial maka plastik menjadi pilihan yang masuk akal bagi perempuan karena terjangkau dan banyak model yang menarik. Bahan lain seperti besi, bambu dan rotan tidak muncul dalam penggalian data.

Pertimbangan pemilihan perabot lebih berdasar pada keputusan suami jika suami memiliki ketrampilan untuk memodifikasi dan memperbaiki perabot yang rusak.

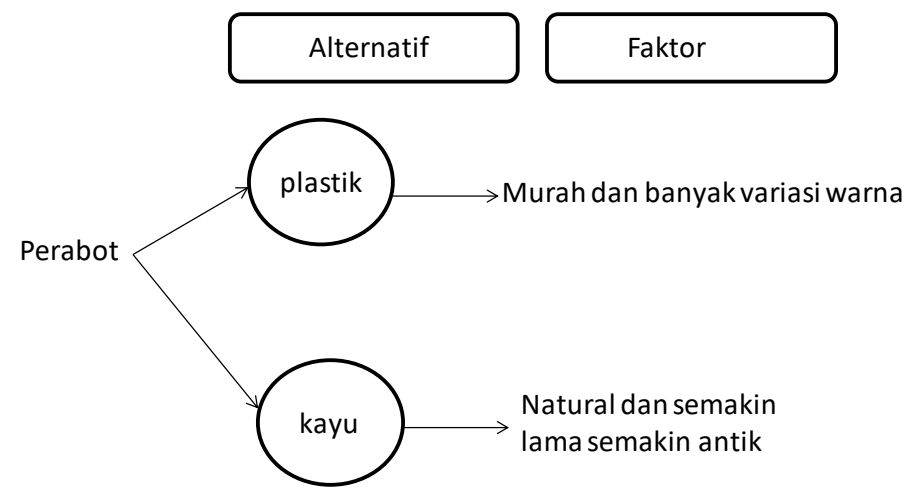

Gambar 3 Alternatif, keputusan dan faktor penentu keputusan oleh perempuan dalam pilihan perabot ( sumber: Analisis, 2020)

\section{Tata Letak}

Tata letak dan penyedian kebutuhan ruang didominasi oleh tema ketersedian lahan dan anggaran pembangunan. Selain itu muncul tema ekstensi bangunan untuk masa mendatang. Penentuan ini lebih didasarkan pada keputusan laki-laki. Terdapat temuan menarik bahwa istri yang aktif diluar rumah cenderung untuk mempercayakan pengaturan tata letak kepada suami. Istri yang terlibat aktif dalam kegiatan sosial di luar rumah tidak terlalu berperan dalam menentukan bagaimana rumah tinggal ditata dan dikelola.

Perempuan biasanya terlibat aktif dalam pengambilan keputusan penataan ruang jika dirinya menggunakan ruang secara intensif seperti pada ruang tamu dan dapur. Perempuan yang banyak menerima teman-teman perempuannya memutuskan untuk menata ruang tamu sesuai dengan citra dan keinginannya.

Hasil amatan dilapangan menunjukkan bahwa tata letak ruang menggunakan pola linear yang menempel di sepanjang dinding rumah. Pola linear ini merupakan pola yang mudah untuk diikuti dan dimodifikasi jika kondisi membutuhkan perubahan untuk pertemuan warga atau arisan. Tidak dijumpai tata letak yang menggunakan fixed furniture di dalam interior yang diteliti. Tipe penataan semacam ini sebetulnya lebih efektif untuk menampilkan citra namun kurang fleksibel untuk kondisi sosial di wilayah Karangwaru.

Salah satu responden yang menghuni rumah kontrakan memiliki tata letak rumah yang unik, rumah tersebut menempel di dinding dalam bentuk kamar-kamar linear dan memiliki courtyard di tengahnya. Secara umum bentuk tata letak ruang yang seperti ini kurang cocok untuk kehidupan keluarga karena mirip dengan kamar kos yang berderet-deret. Mereka tampaknya menyewa 3 kamar untuk hidup satu keluarga sehingga memiliki setting hunian yang unik. Perempuan yang tinggal di rumah kontrakan tidak memiliki peran dalam memutuskan desain yang sesuai dengan 
keinginannya. Hal ini disebabkan karena selain keterbatasan finansial mereka juga memiliki keterbatasn otoritas untuk melakukan perubahan fisik rumah yang ditempatinya.

Tata letak bagi perempuan lebih ditakankan pada fungsi (gb.4) daripada citra ruang. Ruang ruang seperti dapur ditata sesuai dengan kebutuhan fungsional mereka untuk kegiatan memasak yang membutuhkan waktu cukup panjang. Citra ruang sebetulnya penting bagi perempuan namun dapat diabaikan jika mereka menghadapi keterbatasn finansial.

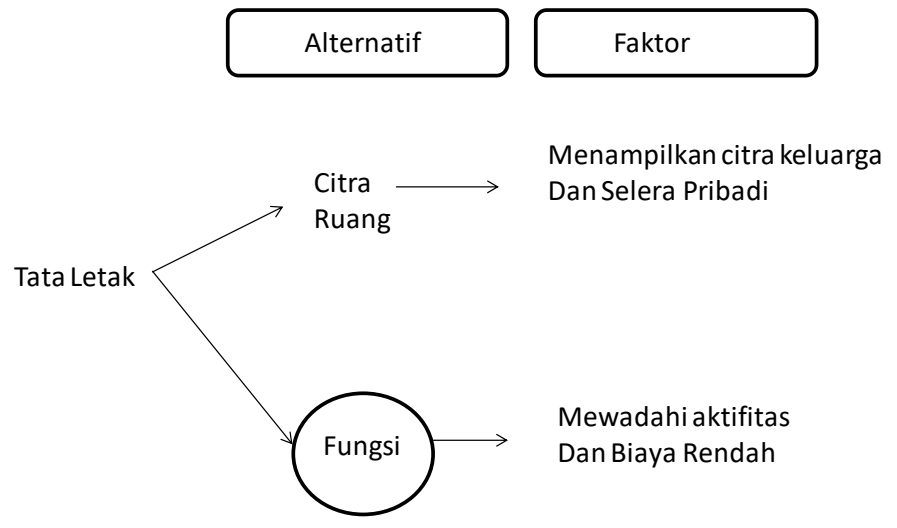

Gambar 4 Alternatif, keputusan dan faktor penentu keputusan oleh perempuan dalam menentukan penekanan tata letak ruang ( sumber: Analisis, 2020)

\section{Faktor-Faktor Pendukung Peran Perempuan dalam Membuat Keputusan Desain}

\section{Pengetahuan Desain dan Prosedur}

Tahap persiapan pembangunan seperti pengurusan ijin dan berhubungan dengan tukang pada umumnya dilakukan oleh laki-laki. Mereka dianggap lebih mengetahui dan lebih mudah berhubungan dengan para tukang-tukang dalam proses koordinasi dan perintah kerja. Pengetahuan tentang teknis pembangunan dan kemudahan mengakses informasi dalam masalah perijinan dan tata bangunan menjadi faktor utama ketika dalam memutuskan siapa yang akan bertanggung jawab untuk melakukan pekerjaan tersebut.

Beberapa responden perempuan dari kelompok menengah ke bawah justru lebih banyak berperan dalam pengurusan ijin dan tahap persiapan pembangunan awal. Hal ini kemungkinan disebabkan karena kelompok ini memiliki tingkat pengetahuan yang sama antar suami dan istri sehingga tidak menjadi masalah siapa yang akan melakukan pekerjaan tersebut. Ada kecenderungan pada responden yang memiliki keterbatasan ekonomi justru berbagi peran lebih leluasa tanpa memiliki stereotype khusus terhadap jenis pekerjaan tertentu.

Responden yang lebih mapan justru menampakkan pembagian peran tradisional seperti memberikan peran publik kepada laki-laki dan perempuan mengurus persoalan domestik. Hasil wawancara menunjukkan bahwa perempuan dari kelompok mapan sebetulnya mampu untuk mengakses informasi tentang perijinan dan peraturan tata bangunan, akan tetapi mereka memilih untuk menyerahkan peran tersebut kepada laki-laki.

Peran untuk menampilkan citra interior yang sesuai dengan citra yang diinginkan banyak diambil oleh perempuan. Faktor yang mendorong perempuan untuk mengambil peran tersebut adalah 
pengetahuan mereka tentang pernik-pernik asesoris rumah dan kemampuan mereka untuk menata ruangan dengan mencocokan antara asesoris dan perabot.

\section{Kepemilikan}

Faktor kepemilikan menjadi penting dalam menentukan peran sentral selama pembangunan rumah. Tanah yang dimiliki oleh perempuan akan membuat laki-laki mengambil peran sebagai "pendamping" atau hanya membantu mengurusi sesuai dengan keinginan perempuan. Keputusankeputusan penting yang berhubungan dengan desain awal tetap ada ditangan perempuan. Mereka memutuskan arah hadap, menentukan apakah rumah tersebut berlantai satu atau dua serta memberikan ketentuan-ketentuan tentang bagaimana ruang jemur dan dapur harus diletakkan.

Responden perempuan yang "ikut" dalam keluarga suami juga mengalami hal yang sama. Mereka bahkan sama sekali tidak berpartisipasi dalam menentukan keputusan desain. Salah satu responden bahkan tidak "berani" untuk mengusulkan pemindahan sumur yang ada di tengah ruang tamunya. Meskipun sumur tersebut ditutup dengan beton, dirinya masih tetap khawatir dengan keselamatan anggota keluarga lainnya. Keputusan yang diambil untuk mengatasi masalah tersebut adalah meletakkan meja di atas sumur agar tidak menjadi jalur pergerakan di dalam rumah.

Responden yang mengontrak dan tidak memiliki kepemilikan lahan mengalami situasi yang lebih apatis. Perempuan memang lebih peka terhadap kerusakan-kerusakan yang terjadi di dalam area kerjanya seperti dapur dan tempat cuci. Mengontrak menyebabkan mereka tidak bisa langsung memutuskan untuk memperbaiki kerusakan karena berdampak pada pemilik rumah. Terkadang rumah yang dikontrak berhimpit dengan rumah utama atau rumah pemilik kontrakan, sehingga jika ada atap bocor tidak mungkin hanya diperbaiki dari satu sisi saja. Mereka biasanya membiarkan kerusakan tersebut apa adanya sampai ada keputusan dari pemilik rumah. Keterbatasan ini membuat mereka harus menerima kondisi rumah apa adanya dan melakukan improvisasi dengan barang-barang yang tersedia tanpa melakukan perubahan signifikan.

\section{Citra Ruang}

Citra ruang merupakan hal penting bagi perempuan. Mereka memilih citra dengan pertimbangan imajinatif dan realistis. Jika keterbatasan finansial membuat mereka tidak bisa memenuhi keinginannya maka mereka akan melakukan modifikasi citra sesuai dengan kemampuannya.

Responden yang menggunakan ruang tamu dengan intensif memilih untuk mengambil peran dalam menentukan citra dan tata letak yang sesuai dengan kepribadiannya. Ruang-ruang yang tidak berhubungan dengan dirinya atau lebih banyak dipakai oleh suaminya tidak menjadi prioritas bagi dirinya. Citra ruang ini berhubungan dengan bagaimana dirinya ditampilkan dalam ruang-ruang yang dipakai olehnya sehari-hari. Ketika ruang-ruang tersebut dipakai bersama teman-temannya maka kebutuhan citra ini menjadi semakin penting.

Citra fasad bangunan tidak menjadi perhatian utama bagi perempuan, mereka lebih memanfaatkan pernik asesoris ruang dan perabot untuk menampilkan citra pribadinya. Cat warna dinding biasanya diserahkan kepada laki-laki. Ada kemungkinan perempuan tidak tertalu memperhatikan warna dinding karena dianggap sebagai "wilayah" laki-laki. 


\section{Pemakaian Ruang}

Ruang-ruang seperti ruang jemur, ruang cuci, dapur dan ruang tamu sering menjadi "wilayah" perempuan dalam penentuan desainnya. Mereka secara aktif menentukan "kriteria desain" untuk ruang tersebut. Misalnya mereka memutuskan bahwa ruang jemur harus di lantai dua atau memutuskan ruang tamu harus memiliki citra khusus.

Pemakian ruang dapur menjadi penting bagi perempuan karena mereka bisa menghabiskan waktu lama di dalamnya. Meskipun perawatan dan perbaikan untuk ruang tersebut menjadi tanggung jawab suami seringkali perempuan tetap harus melakukan perbaikan kecil jika situasinya sangat mendesak.

Ketika perempuan aktif berkegiatan di luar rumah maka mereka cenderung untuk tidak memutuskan apapun untuk penggunaan ruang ruang tersebut. Pemakaian menjadi salah satu faktor penting yang mendorong perempaun untuk memutuskan apakah dirinya akan terlibat aktif untuk memutuskan desain ruang atau tidak. Jika suami lebih banyak memakai ruang tersebut maka suami akan banyak membuat keputusan di dalamnya.

\section{Keselamatan}

Perempuan menempatkan keselamatan dan kesehatan lebih dari estetika dalam memutuskan keputusan desain. Namun demikian estetika dapat menjadi indikator kesehatan dan keselamatan, hal ini menyebabkan keputusan desain perempuan sepintas memiliki penekanan pada estetika. Saat memutuskan arah hadap rumah yang membelakangi sungai mereka mengatakan bahwa sungai saat itu kotor dan bau sehingga mereka takut akan mengganggu kesehatan keluarga lainnya. Banyaknya nyamuk dan kemungkinan binatang liar seperti ular menjadi penyebab mereka memutuskan untuk menghadapkan rumah ke jalan kampung dari pada ke arah sungai. Jika pertimbangan estetis menjadi pendorong utama maka kemungkinan rumah rumah yang ada di bibir sungai akan dihadapkan ke arah sungai untuk mendapatkan view yang menarik.

Hasil wawancara menunjukkan bahwa kondisi sungai saat rumah dibangun memang kumuh dan kotor sehingga sama sekali tidak menarik sebagai arah hadap rumah. Potensi estetis yang dimiliki oleh sungai tidak membuat mereka berusaha membersihkan areanya dan mendapatkan pemandangan yang bersih. Opsi tersebut tidak praktis untuk mereka dan terlalu berbahaya untuk kondisi saat itu sehingga mereka memutuskan untuk mencari pemecahan yang lebih pragmatis.

Responden yang memiliki sumur di ruang tengah juga terlihat sangat khawatir dengan kondisi keselamatan keluarga. Keputusannya untuk menempatkan perabot di atasnya menunjukkan bahwa faktor keselamatan menjadi penentu untuk memutuskan keputusan desain.

\section{Simpulan}

Peran perempuan dalam keputusan desain di rumah tinggal mereka memiliki spektrum yang berbeda-beda. Tingkat sosial tidak menjadi penentu dalam mengambil peran untuk terlibat aktif dalam mengambil keputusan desain. Faktor-faktor yang berperan dalam keputusan desain diantaranya adalah pengetahuan mereka terhadap persoalan desain, jika mereka mengusainya mereka akan berperan aktif untuk memutuskan. Pengetahuan ini tidak selalu menjadi penentu keputusan karena jika mereka tidak dalam posisi pemilik lahan peran mereka menjadi berkurang.

Faktor keselamatan juga menjadi perndorong perempuan untuk mengambil keputusan desain. Pilihan desain yang menimbulkan bahaya akan cenderung dihindari oleh perempuan meskipun 
memiliki nilai estetis. Mereka juag terlibat aktif dalam mengambil keputusan jika ruang tersebut dipakai sebagai tempat aktifitasnya.

Secara umum perempuan mengambil keputusan desain dengan pertimbangan yang pragmatis dan praktis. Mereka menerima kekuarangan dari kondisi rumah tinggal dengan melakukan keputusan desain dalam batas kemampuan finansial dan memenuhi kebutuhan fungsionalnya. Jika kondisi memungkinkan maka citra akan menjadi faktor yang mendorong mereka untuk mengambil keputusan desain.

\section{Daftar Pustaka}

Almendra, R., \& Christiaans, H. (2009). Decision-Making in Design:a Comparative Study. International Conference on Research into Design. Research publishing Service.

Choi, I., Choi, J. A., \& Norenzayan, A. (2004). Culture and Decision. Dalam D. J. Koehler, \& N. Harvey, Handbook of Judgement and Decision Making (hal. 504-524). Oxford: Blackwell Publishing.

Leavy, P. (2017). Research Design. New York: The Guilford Press.

Nurhamida, Y. (2013). Power in Marriage pada Ibu Bekerja dan Ibu Rumah Tangga. Jurnal Psikogenesis, 185-198.

Putri, F. R., \& Rucitra, A. A. (2013). Desain Interior House of Eve Sebagai Muslimah Beauty Center Dengan Nuansa Islami Kontemporer. Jurnal Sains dan Seni Pomits, 1-5.

Setiawati, E., Malihah, E., \& Komariah, S. (2017). Faktor-Faktor yang Mempengaruhi Perempuan Berpendidikan Tinggi Berperan Sebagai Pengambil Keputusan dalam Keluarga di Kelurahan Isola. Sosietas, 329-334.

Siswati, M. K., \& Puspitawati, H. (2017). Peran Gender, Pengambilan Keputusan dan Kesejahteraan Keluarga Dual Earner. Jurnal Ilmu Keluarga dan Konsumen, 169-180. 